\title{
LITIGATING INDIGENOUS PEOPLES' RIGHTS IN AFRICA: POTENTIALS, CHALLENGES AND LIMITATIONS
}

\author{
Jérémie Gilbert*
}

\begin{abstract}
Adopting a comparative analysis, this article examines some of the recent cases of litigation which have focused on indigenous peoples' rights across the African continent. The aim is to explore the potentials but also the challenges and limitations of litigation as a tool for supporting the rights of indigenous peoples in Africa. The article explores to what extent an African jurisprudence is emerging from these cases on issues that are essential to indigenous peoples such as non-discrimination, self-identification, land rights and development. It also focuses on the practical issues that arise with engaging with litigation to explore to what extent it could contribute to the legal empowerment of some of the most marginalised communities in Africa.
\end{abstract}

\section{INTRODUCTION}

It is estimated that approximately 50 million indigenous peoples live across the African continent. ${ }^{1}$ Commonly across the continent, they face hardship, discrimination, non-recognition of their rights to lands and natural resources, as well as high level of economic, social and cultural marginalization. ${ }^{2}$ In many parts of Africa, indigenous communities are forced out of their ancestral lands to make room for the establishment of wildlife reserves, tourism resorts, or to allow the extraction of natural resources. All these issues have been examined and analysed in a groundbreaking report issued in 2003 by the Working Group on Indigenous Populations/Communities of the African Commission on Human and Peoples' Rights which provides an in-depth analysis of the situation of indigenous peoples in Africa. ${ }^{3}$

\footnotetext{
* Professor of International and Comparative Law, University of East London (UK), contact: jeremie.gilbert@uel.ac.uk This article is based on a presentation given at the Half-Day Workshop on 'Adjudication and Indigenous Peoples' organised at Queen Mary University, London in January 2016. The author would like to thanks Chris Kidd, Ben Begbie-Clench, Maria Sapignoli, Lucy Claridge and Paul McHugh for comments on an early draft of the article.

${ }^{1}$ See International Work Group on Indigenous Affairs, at http://www.iwgia.org/regions/africa

${ }^{2}$ On the situation of indigenous peoples in Africa, see R. Laher and K. Singí Oei (eds), Indigenous People in Africa: Contestations, Empowerment and Group Rights (Africa Institute of South Africa, 2014); S. Dersso (ed.), Perspectives on the Rights of Minorities and Indigenous Peoples in Africa (PULP, 2010)

3 Report of the African Commission's Working Group of Experts on Indigenous Populations/Communities submitted in accordance with 'Resolution on the Rights of Indigenous Populations/Communities in Africa adopted by the African Commission on Human and Peoples' Rights at its 28th ordinary session (2005).
} 
As noted in this report, the rights of indigenous peoples are often a very controversial and complex issue across the continent. The definition and scope of indigenous peoples' rights are usually contentious in most African countries. At the national level, most of the States are still reluctant to recognise the specific rights of indigenous peoples. ${ }^{4}$ The term 'indigenous peoples' itself is usually seen as contentious issue. ${ }^{5}$ The term is often seen as a "western invention", which might be relevant in countries which have witnessed large influx of white settlers such as Australia, the United States or Canada, but not for Africa. Several States have argued that the reference to being "first and original occupants" of a territory, which is implied by the term indigenous, is not relevant to Africa. ${ }^{6}$ This debate on the definition of who are the indigenous peoples of Africa, and whether this legal category is relevant to the continent, has undermined progress on the protection of the rights of indigenous peoples in Africa. ${ }^{7}$

There are signs of the emergence of new legal frameworks to recognise and protect indigenous peoples' rights across the continent. The new constitution of Kenya, adopted in 2010, recognises "historically marginalized groups", including indigenous peoples. The constitution of Cameroon also mentions indigenous peoples, and in Burundi the constitution provides for special representation of the indigenous Batwa people in the National Assembly and the Senate. In 2010, the Central African Republic became the first African country to ratify the ILO Convention No. 169; and in 2011, the Republic of Congo became the first African country to adopt a specific law on the promotion and protection of the rights of indigenous populations. Nonetheless, despite these significant changes in the legal landscape relating to indigenous peoples' rights, most indigenous peoples still do not have access to legal remedies, and most national legal systems do not specifically recognise and protect their rights. With this lack of specific legal protection, one solution is often to turn to courts to seek legal remedies. There have been considerable efforts by many communities across the continent to develop their legal and advocacy capacity to seek legal remedies. ${ }^{8}$ In the last few years, many communities have engaged with litigation as a potential way to get the recognition of their rights and challenge the discrimination they face. There have been some important decisions at the regional level, notably with the adoption of a decision against Kenya in 2010 by the African Commission on Human and Peoples' Rights Commission concerning the indigenous

\footnotetext{
${ }^{4}$ See: F. Thornberry and F. Viljoen, Overview Report on the Constitutional and Legislative Protection of the Rights of Indigenous Peoples in 24 African Countries (International Labour Organization and African Commission on Human and Peoples' Rights, 2009).

${ }^{5}$ W. van Genugten, "Protection of Indigenous Peoples on the African Continent: Concepts, Position Seeking, and the Interaction of Legal Systems", (2010) 104 (1) A.J.I.L. 29

${ }^{6}$ See: J. Ngugi, "The Decolonisation-modernisation Interface and the Plight of Indigenous Peoples in Post-colonial Development Discourse in Africa", (2002) 20 Wisconsin International Law Journal 289

${ }^{7}$ See F. Mukwiza Ndahinda, Indigenousness in Africa: A Contested Legal Framework for Empowerment of 'Marginalized' Communities (Springer, 2011)

${ }^{8}$ See G. Wachira Mukundi, and T. Karjala, 'Advocacy for indigenous peoples' rights in Africa', in Indigenous People in Africa: Contestations, Empowerment and Group Rights (2014): 104.
} 
Endorois community. ${ }^{9}$ The decision has been hailed as a "landmark" as it touches on several crucial issues regarding the development of indigenous peoples' rights in Africa. ${ }^{10}$ There is also one case that is currently examined by the recently established African Court on Human and Peoples' Rights. ${ }^{11}$ In parallel to the emergence of a regional jurisprudence on indigenous peoples' rights, there is an increased use of national courts as a place to seek remedies and recognition by indigenous peoples. In the last decade there has been some important cases at the national levels, including rulings form the High Court of Botswana ${ }^{12}$, the Constitutional Court of South Africa, or the High Court of Uganda ${ }^{13}$ for examples. There are also important cases that are currently been examined by the Constitutional Court of Uganda and the High Court of Namibia. ${ }^{14}$

This articles wishes to examine some of these cases to assess their potential impact for the protection and the development of indigenous peoples' rights. The aim is to explore the potentials but also the challenges and limitations of litigation as a tool for supporting the rights of indigenous peoples in Africa. For that purpose the article focuses on cases that have been articulated as being within the legal field of indigenous peoples' rights, either by the applicants, the judges, the lawyers or civil society advocates involved in the cases. This includes cases which have been finally ruled, having reached the highest level of possible appeal, or cases which are still ongoing within the court system. Apart from the content of the cases and the jurisprudence they create, it is important to analyse these cases in terms of the larger legal, political, economic and social impact they have (or not) to promote and protect the rights of indigenous peoples. Increasingly questions have been raised about the 'value' of litigation, and more specifically about strategic litigation, as an efficient tool to challenge embedded forms of discrimination faced by indigenous peoples. An issue which notably relates to the lack of implementation of the courts' decisions, but also the cost and time involved in litigation, as well as the limitations of the legal language to address very complex socio-economical issues faced by indigenous

\footnotetext{
${ }^{9}$ Communication 276/2003, Centre for Minority Rights Development (Kenya) and Minority Rights Group International on behalf of Endorois Welfare Council v Kenya (2010)

${ }^{10}$ See J. Gilbert, “Indigenous Peoples' Human Rights in Africa: the Pragmatic Revolution of the African Commission on Human and Peoples' Rights", International and Comparative Law Quarterly 60.01 (2011): 245-270.

${ }^{11}$ In March 2013 the Court issued an order of provisional measures in respect of the situation of the Ogiek of the Mau Forest in Kenya, prohibiting land transactions in the Mau Forest Reserve protected area and other actions likely to prejudice the Ogiek's claim. The case was heard in November 2014 and the case remains pending, with judgment scheduled for 2017.

12 Roy Sesana (First Applicant), Keiwa Setlhobogwa and 241 others, (Second and Further Applicants) v. the Attorney General of the Republic of Botswana, High Court of Botswana, 2006; and Matsipane Mosethanyene (First Appellant) and Gakenyatsiwe Matsipane (Second Appellant,) v. the Attorney General (Respondent), High Court of Botswana, 27 January, 2011.

13 Consent Judgment and Decree, Uganda Land Alliance, Ltd. v. Uganda Wildlife Auth., Miscellaneous Cause No. 0001 of 2004 (High Court of Uganda at Mbale)

14 The case concerns the forced eviction of the San from the Etosha National Park. A demand for a class action is presently examined by the court, see http://www.osisa.org/indigenouspeoples/namibia/haiom-set-make-legal-history-etosha-aboriginal-land-claim
} 
peoples. Overall, the aim of this article is to explore the potentials of litigation as a tool for advocacy across the continent.

To undertake this task, the article is divided into four different thematic sections. The first section examines how courts have engaged with the legal concept of indigenous peoples, notably focusing on definition and discrimination. The second section explores how courts have dealt with the crucial issue of land rights, which is seen as essential elements of indigenous peoples' rights. ${ }^{15}$ The third section focuses on the issue of development, conservation and tourism, three 'ingredients' that often result in the forced displacement of indigenous peoples. It examines how courts have dealt with the argument put forward by States authorities that the forced displacement of indigenous communities is necessary to support development, enhance conservation or promote tourism. The final section is focusing on legal strategies with the aim of critically examining the value of litigation as tool of empowerment for marginalised indigenous communities.

\section{I. 'INDIGENOUSNESS', ‘AUTHENTICITY'AND DISCRIMINATION}

Most, if not all, indigenous communities face discrimination, lack of recognition and marginalisation. In most cases the first step in litigation is to claim their right as indigenous peoples, to be recognised as citizens of the State with equal rights, but also with special entitlement against discrimination to fight embedded forms of racism they are usually facing. At the heart of this claim is the call to recognise that, as a specific category of rights holders, indigenous peoples are entitled to be recognised as holders of specific non-discriminatory policies. ${ }^{16}$ Most governments across the continent have resisted the development of specific legislations, or policies, which would put in place special measures to address the entrenched discrimination faced by indigenous peoples. Many governments have put forward the argument that all inhabitants are indigenous to the continent, and that therefore the concept of 'indigenous peoples' as developed under international law is irrelevant. ${ }^{17}$ Governmental policies and directives often rely on a colonial approach to the notion of 'indigenous' or 'native' peoples under which all Africans (as opposed to settlers and colonisers) were labelled as 'indigenous' or 'natives'. The notion of indigenous peoples has greatly evolved over the last few decades, acquiring a contemporary interpretation, which modifies the colonial approach which defined all

\footnotetext{
${ }^{15}$ A. Barume, Indigenous Peoples Land Rights in Africa (International Work Group for Indigenous Affairs, $2^{\text {nd }}$ revised edition 2015).

${ }^{16}$ See Benedict Kingsbury, "Reconciling Five Competing Conceptual Structures of Indigenous Peoples' Claims in International and Comparative Law", NYUJ Int'l L. \& Pol. 34 (2001): 189; Patrick Thornberry, "Confronting racial discrimination: a CERD perspective", 5.2. Human Rights Law Review 239-269 (2005)

${ }^{17}$ See Albert K. Barume, "Responding to the Concerns of the African States", in Claire Charters, and Rodolfo Stavenhagen (eds.), Making The Declaration Work: The United Nations Declaration on The Rights of Indigenous Peoples (IWGIA, 2009)
} 
the inhabitants of the continent as 'indigenous' and 'natives'. Hence an important element the litigation process is often to get court to apply and recognise this contemporary approach to indigenous peoples' rights.

\section{A. 'Authenticity' and 'Indigenous' Rights in Botswana}

Over the last decade Botswana has been at the centre of litigation on indigenous peoples' rights, which has attracted significant attention nationally, regionally and internationally. ${ }^{18}$ At the heart of the legal battle was the claim of the San and Bakgalagadi residents of the Central Kalahari Game Reserve (CKGR) Botswana's largest protected area and the second largest game reserve in Africa - that they had been illegally removed from their ancestral land by the government. There have been issues about the rights of the indigenous community in the CKGR for many years as the reserve was established in 1961, but everything accelerated in 1997 when the people of Xade in the reserve were relocated, and the situation worsened in 2002 when the government informed the remaining residents of the CKGR that they were shutting down the wells and stopping all food deliveries inside the reserve. ${ }^{19}$ The government then proceeded with the removal of the peoples and their possessions out of the reserve. The residents decided to challenge their removal in court. ${ }^{20}$

Whilst the litigation was mainly about determining the rights to land and services for the indigenous communities, the issue of determining the specific rights of the CKGR inhabitants as an indigenous community was also fundamental. The government of Botswana is well-known for its opposition to the notion of indigenous peoples' rights. ${ }^{21}$ A constant argument of the government's lawyers in the court case was that the San residents of the CKGR were not entitled to any specific rights, but should be treated as any other citizens of the State. Based on this approach, the argument put forward was that the San resident of the CKGR should be removed from their land to ensure their access to 'modernisation' and 'progress' like any other citizens of the country. One of the justifications to justify their forced relocation was to bring their standards of living up to the level of the rest of the country. As the minister for local government put it: "We as governments simply believe that it is

18 Central Kalahari Legal Case No. MISCA 52/2002 in the Matter between Roy Sesana, First Applicant, Keiwa Setlhobogwa and 241 others, Second and Further Applicants, and the Attorney General High Court of Botswana (2006); High Court Civil Case No. MAHLB 000 393-09 In the matter between Matsipane Mosetlhanyene, First Appellant, and Gakenyatsiwe Matsipane, Second Appellant, and the Attorney General Respondent (2011)

${ }^{19}$ See: M. Sapignoli and R. Hitchcock, "A Chronology of the Central Kalahari Game Reserve: Update III, 2002 - 2012, Botswana Notes and Records, Volume 45; and R. Hitchcock, M. Sapignoli, and W. Babchuk, "What about Our Rights? Settlements, Subsistence, and Livelihood Security among Central Kalahari San and Bakgalagadi" 15 (1) The International Journal of Human Rights (2011), 67-87.

20 Their case was first dismissed but went on appeal in to the High Court, see: High Court of Botswana, Roy Sesana, Kiewa Setlhobogwa, \& 241 Others v the Attorney General of Botswana, Case No. 52 of 2002.

${ }^{21}$ Botswana was one of the governments which derailed the process for the adoption of the UN Declaration on the Rights of Indigenous Peoples in 2006. 
totally unfair to leave a portion of our citizen undeveloped under the pretext that we are allowing them to practice their culture." 22 During the trial, the government's lawyers put forward the fact that the applicants" were "no longer authentic" because they were not hunting and gathering full-time, as they had in the past, and were involved in agriculture, livestock production, and migrant labour. On the other side of the spectrum, the legal counsel for the applicants referred to the concept of indigenous peoples rights as developed under international law, highlighting the need for the court to recognise their entitlements as specific indigenous rights. As analysed by Hitchcock, Sapignoli and Babchuk:

The San of Botswana, in defining themselves as 'indigenous' before and during the Central Kalahari court case, did so purposely. They sought to re-assert their rights, using the concept of indigeneity as a means of defining themselves as a group that: (1) was different from the majority population; (2) that historically had been mistreated and discriminated against; and (3) that this treatment occurred in part because of their lifestyles and distinct cultural attributes. $^{23}$

The recognition of the concerned CKGR residents as indigenous peoples was an important element of their legal claims. Most important was to recognize the CKGR inhabitants as the "Bushmen" mentioned in Article 14.3.c of the Constitution, as the people having certain rights to reside in Reserve. As noted by Sapignoli, the San and Bakgalagadi "in speaking about indigeneity, entering the Court and adopting its language, found a way to obtain their rights." ${ }^{24}$ As she noted: "(...) indigeneity in Africa is a recent identity claim born in the 1990s with the emergence of the international indigenous movement and international law and organizations on indigenous peoples. The Botswana Court Case and Bushmen's self-identification as indigenous peoples cannot be understood without considering these local, national, and global relationships." 25 During the court hearings a lot of emphasis was put on the anthropological experts to 'prove' the originality and 'authenticity' of the indigenous claims. Ultimately, the High Court recognised the right of the community to live on their ancestral territory. In reaching this decision, two of the judges, specifically highlighted the need to recognise them as indigenous, with Justice Dow noting: "the fact the applicants belong to a class of peoples that have now come to be recognized as 'indigenous peoples' is of relevance." 26 As highlighted by the judge this meant that the relevant international legal principles regarding indigenous peoples' rights, and notably the Convention of the Elimination of All Forms of Racial Discrimination

\footnotetext{
22 CCJ 2006, Bundle 1A 104 (ExP32)- Letter from Minister Margaret Nasha to Ditshwanelo, dated 7 January 2002- as quoted in M. Sapignoli, "Dispossession in the Age of Humanity: Human Rights, Citizenship, and Indigeneity in the Central Kalahari”, (2015) 25 (3) Anthropological Forum, pp. 285-305

23 R. Hitchcock, M. Sapignoli, and W. Babchuk, supra note 19, at 63.

${ }^{24}$ M. Sapignoli, "Indigeneity and the expert: Negotiating identity in the case of the Central Kalahari Game Reserve", (2009) 12 Law and Anthropology: Current Legal Issues 247-68.

25 Ibid, at 267.

26 CCJ, 2006, at 201.
} 
(ICERD) were relevant to the case. ${ }^{27}$ More generally, all the judges accepted the fact that being recognised as 'indigenous peoples' meant that the colonial acquisition of their land and the following post-independence land legislation had not extinguished their rights to use their ancestral territories. Knowing how the government was putting pressure on rejecting this legal approach recognising the relevance of indigenous peoples' rights in the country, this certainly is an important legal development.

\section{B. The 'Invisible' Batwa of Uganda}

In 2013, several members of Batwa communities of Southwest Uganda have submitted a petition to the Constitutional Court. ${ }^{28}$ The petition is seeking recognition of their status as indigenous peoples, redress for the historic marginalisation and discrimination they are facing, and compensation for the continuous human rights violations they have experienced as a result of being dispossessed of their ancestral lands. The Batwa have been gradually evicted from their lands following the creation of national parks in the forests covering their ancestral territories. ${ }^{29}$ The establishment of these national parks started during the colonial time in the 1930s, but many Batwa continued to live in the forest and to use its resources until the 1990s when they were evicted, without consultation, adequate compensation or offer of alternative land. As a result the Batwa have been living at the borders of the parks becoming squatters on other peoples' land, leading them towards severe poverty, malnutrition and health problems. ${ }^{30}$ This loss of their lands and sources of livelihood is accentuated by the high levels of discrimination they are facing in the Ugandan society. ${ }^{31}$ In general, the Batwa suffer from extreme and embedded forms of discrimination from the mainstream society. ${ }^{32}$ As a result they notably suffer from forced labour, lack of

\footnotetext{
${ }^{27}$ On the role of ICERD and indigenous peoples, see: P. Thornberry, Indigenous Peoples and Human Rights (Manchester UP, 2002), pp. 199-ss

${ }^{28}$ For detailed information about the Batwa, see: J. Lewis, The Batwa Pygmies of the Great Lakes Region (MRG, 2000); J. Woodburn, "Indigenous discrimination: the ideological basis for local discrimination against hunter-gatherer minorities in sub-Saharan Africa", Ethical and Racial Studies, Vol. 20, No.2, 1997, pp. 345-361; Jackson, D., Twa Women Twa Rights in the Great Lakes Region of Africa, (Minority Rights Group International, 2003); Nelson, J. and Hossack, L. (eds.), From principles to practice: Indigenous peoples and protected areas in Africa (Forest Peoples programme, 2003).

${ }^{29}$ The Batwa's ancestral territory covers several areas of the Bwindi Impenetrable National Park, Mgahinga Gorilla National Park and Echuya Central Forest Reserve.

${ }^{30}$ Lea Berrang-Ford and all, "Vulnerability of indigenous health to climate change: A case study of Uganda's Batwa Pygmies", Social science \& medicine 75.6 (2012): 1067-1077; Sherilee Harper, "Social Determinants of Health for Uganda's Batwa", Africa Portal, June 2012: 32.

${ }^{31}$ See: C. Kidd, "Inventing the "Pygmy": Representing the "Other", Presenting the "Self", (2009) 20.4 History and Anthropology 395-418.

32 See: C. Kidd, "Development Discourse and the Batwa of South West Uganda: Representing the 'Other': Presenting the 'Self.'” (Unpublished PhD thesis, Glasgow 2008), available at: http://theses.gla.ac.uk/169/ ; C. Kidd and P. Zaninka, "Securing Indigenous Peoples' Rights in Conservation: A Review of South-West Uganda" (Forest Peoples Programme and United Organisation for Batwa Development in Uganda, 2008).
} 
political representation and participation, lack of access to education, housing, healthcare, social security and benefits. ${ }^{33}$

One of the arguments put forward by the Batwa in their petition to the Constitutional Court relates to their recognition as indigenous peoples. The government has so far rejected their claims as indigenous peoples, not recognising their specific rights to land and natural resources, and not acknowledging the need to develop special measures to address the discrimination they are facing. In its Third Schedule, the 1995 Constitution lists 'indigenous communities'. However, this Schedule is based on its colonial roots listing all the 'Tribes' existing or residing within the colonial borders of Uganda as of 1926. Hence the Constitution adopts a very colonial tone by labelling all ethnic groups of the country as indigenous peoples, but not putting in place special measures of protection for the most marginalised indigenous communities. In the petition and in the experts affidavits submitted to the Constitutional Court, the importance of using contemporary standards of definition used at international and regional levels has been put forward as an essential element of their claim. The petitioners have invited the Court to consider the definition proposed by the Working Group on Indigenous Population/Communities of the African Commission (WGIP) which defines indigenous peoples based on the characteristics that:

a) their culture and way of life differ considerably from the dominant society, to the extent that their culture is under threat of extinction;

b) the survival of their particular way of life depends on access to lands and natural resources;

c) they suffer from discrimination as they are being regarded as less developed and less advanced than other more dominant sectors of society;

d) they often live in inaccessible regions and are often geographically isolated;

e) they are subject to domination and exploitation within national political and economic structures. $^{34}$

The petitioners have further highlighted that the African Commission has further clarified that the term indigenous populations does not mean 'first inhabitants' in reference to aboriginality as opposed to non-African communities or those having come from elsewhere. As noted by the African Commission: “....if the concept of indigenous is exclusively linked with a colonial situation, it leaves us without a

\footnotetext{
33 See: K. Kabananukye and D. Kwagala, Culture, Minorities and linguistic Rights in Uganda: The Case of The Batwa and The Ik (KHURIPEC working paper No.11); N. Mukasa, "The Batwa Indigenous People in Uganda and their Detachment from Forest Livelihood: Land Eviction and Social Plight", (2012) Yearbook on Humanitarian Action and Human Right 71-84; The Parliament of the Republic of Uganda, The Equal Opportunities Committee's Working Visit to Bundibugyo and Kisoro Report (Government of Uganda, 2007)

34 Report of the African Commission Working Group of Experts on Indigenous Population/Communities submitted in accordance with the 'Resolution on the rights of indigenous peoples/communities in Africa' and adopted by the African Commission at its 28th ordinary session in November 2003 and published in 2005
} 
suitable concept for analyzing the internal structural relationships of inequality that have persisted from colonial dominance." 35

Relying on this approach, the petitioners want to challenge the historical (and colonial) classification of all tribes of the country as indigenous, and get a formal legal recognition by the court of their status as indigenous peoples. Hence, an important aspect of the petition is the demand to the Constitutional Court to recognise their self-identification as indigenous peoples as defined under international law. This recognition would notably entitle them to have access to specific affirmative action policies. Article 32 of the Constitution affirms that the government "shall take affirmative action in favour of groups marginalised on the basis of gender, age, disability or any other reason created by history, tradition or custom, for the purpose of redressing imbalances which exist against them." Despite the widespread discrimination faced by the Batwa, the government has not developed any affirmative action polices to tackle such entrenched form of discrimination. In claiming their rights to be recognised as indigenous peoples who are facing historically embedded forms of discrimination, they are inviting the Constitutional Court to declare the government in breach of its constitutional obligation.

This case as well as the previous case concerning Botswana, are showing the importance for the concerned communities to be able to articulate their rights under the banner of indigenous peoples' rights. In these two cases (as well as in the cases that will be examined below), the lack of a proper legal framework coupled with the lack of political will to protect their rights as indigenous peoples has pushed the concerned communities to take legal action against the government. The recognition by the national courts that they are indigenous peoples constitutes an important first step in recognising them as historically discriminated societies entitled to specific rights, notably rights to lands and natural resources as examined below.

\section{IN THE SHADOW OF COLONISATION: THE SURVIVAL OF CUSTOMARY LAND RIGHTS}

Undeniably the colonial history of the continent plays a significant role regarding indigenous peoples' rights, and especially regarding their right to land. Colonial rules had a considerably negative impact on land rights for most indigenous peoples. When their land rights were not ignored they were seriously curtailed and ultimately submitted to the overall control of the colonial administration, notably under the system of trusteeship. This overall rejection of land rights for indigenous

\footnotetext{
35 African Commission on Human and Peoples' Rights, Report of the African Commission's Working Group of Experts on Indigenous Populations Communities, submitted in accordance with the "Resolution on the Rights of Indigenous Populations/Communities in Africa", adopted by the African Commission on Human and Peoples' Rights at its 28th ordinary session (2005), pp. 92-93.
} 
peoples was based on the discriminatory and racist theories of non-usage of the land and lack of 'proper' formal land tenure systems. ${ }^{36}$ In post-colonial Africa many of the independent States have not fundamentally rejected this approach and have maintained a statu quo ante which is often resulting in the forced expulsion of indigenous peoples from their ancestral lands. Hence an important question regarding the value of litigation is the capacity of the courts to reverse centuries of discriminatory practices that have rejected indigenous peoples' land tenure systems as archaic and inexistent.

A critical issue for many indigenous peoples is their lack of formal and official title to prove their land ownership. It is a global phenomenon not limited to Africa, but the colonial legacy and its connection with present day legislations governing land rights has, until recently, not been examined in the context of indigenous peoples' rights. Under international law there is now a strong jurisprudence, notably emerging from the Inter-American Court of Human Rights, highlighting that possession should constitute title to land property. ${ }^{37}$ This jurisprudence also puts forward the importance of recognising indigenous peoples' own customary systems of tenures to recognise their rights to land. This issue has also been an important element of the jurisprudence of some of the common law jurisdictions from the period of the 1970s-1990s. Landmark rulings from Canada, Australia, and New Zealand were based on the central importance of recognising that colonisation, and the post-colonial legal systems, have not extinguished indigenous peoples' land rights. These rights are based on their own customary laws which have 'survived' colonisation and as such need to be recognised and protected by States. ${ }^{38}$ The issue in many African States is not entirely different from that post-colonial concept of Aboriginal or Native Title. Indeed, many communities are facing the same issue of having to 'demonstrate' their right to land based on their actual possession coupled with the claim that their land rights have survived colonisation, and therefore should be recognised and enforced by post-colonial courts. In most African Sates this jurisprudence could have an important effect as indeed most States have suffered from colonisation and its attached doctrines of land dispossessions and imposition of formalistic legal systems that ignored indigenous peoples' ancestral possession. Besides early references to the notion of socalled 'Native Title' in Privy Council decisions, ${ }^{39}$ until recently there was very little

\footnotetext{
${ }^{36}$ See J. Gilbert, Indigenous Peoples' Land Rights under International Law: From Victims to Actors (2nd ed., Brill, 2016)

37 The Mayagna (Sumo) Awas Tingni Community v. Nicaragua, Inter-Am. Ct. H.R., (ser. C) No. 79 (2001); Moiwana Village v. Suriname, Inter-Am. Ct. HR (ser. C) No. 124 (2005); Yakye Axa Indigenous Community v. Paraguay Inter-Am. Ct. HR (ser. C) No. 125 (2005); Sawhoyamaxa Indigenous Community v Paraguay (2006); Case of the Saramaka People v. Suriname Series C No. 172 (2007); Xákmok Kásek Indigenous Community v Paraguay (2010. Series C No. 214); Kichwa People of Sarayaku v Ecuador ( 2012. Series C No. 245); Case of the Kaliña and Lokono Peoples v. Suriname (2015).

${ }^{38}$ For a detailed and critical analysis, see P. McHugh, Aboriginal Title: The Modern Jurisprudence of Tribal Land Rights (OUP, 2011).

${ }^{39}$ See case of Amodu Tijani v. The Secretary of Southern Nigeria, 2 A.C. 399 (1921); In re Southern Rhodesia [1919] A.C. 211, at 223-Privy Council
} 
jurisprudence that had examined this post-colonial legacy of land rights. One of the first cases to examine this colonial legacy was in South Africa.

\section{A. The Survival of Customary Land Rights in South Africa}

Following the post-apartheid legacy on both land rights and nondiscrimination, the courts of South Africa have examined in details the connection between land rights and indigenous peoples' rights in a case which reached both the Supreme Court and the Constitutional Court. ${ }^{40}$ The concerned case was put forward by members of the Richtersveld community who brought a claim for the restoration of their ancestral land under the Restitution of Land Rights Act, a statutory mechanism giving effect to the government's constitutionally-mandated land reform and restitution programme. The Richtersveld community is a community of approximately 3,000 formerly nomadic and pastoralist people, who traditionally occupied a land that was then annexed by Alexkor, a State-owned diamond mine. When the land was annexed, the company argued that the community lost their rights to the land. The government contended that indigenous customary laws on ownership ceased with the annexation of South Africa by the British in 1847, and that this loss of rights was not a dispossession as envisaged under the post-apartheid land restitution act.

An important aspect of the case was the community's assertion that it used the land according to its "indigenous customs" and that such customary law interest had not been extinguished by colonisation and its following apartheid legacy. The case went from the local Land Court to the Supreme Court, and then the Constitutional Court. An essential element for the courts was to define whether the customary land rights of the community could constitute land rights as protected under the restitution of land act. One of the arguments was that the community had a right to the concerned land based on their own indigenous customary land rights, rights that were discriminatory ignored. At the lower levels, the claim was dismissed on the grounds that the claimants were dispossessed for the purpose of mining of diamonds and not because of racially discriminatory laws or practices. In appeal, the Supreme Court of Appeal recognised that the dispossession of the community was racially discriminatory "because it was based upon the false, albeit unexpressed premise that, because of the Ritchersveld community's race and lack of civilization, they had lost all rights in the land upon annexation." 41 The Court highlighted that even though the undisturbed possession of the land by the concerned indigenous community was ignored on discriminatory grounds, indigenous laws regarding land rights had

\footnotetext{
${ }^{40}$ See: T.M. Chan, “The Richtersveld Challenge: South Africa Finally Adopts Aboriginal Title', in Indigenous Peoples Rights in Southern Africa", R.. Hitchcock and D. Vinding (ed.), Indigenous Peoples' Rights in Southern Africa (International Work Group for Indigenous Affairs, 2004), 11430

41 The Ritchersveld Community and Others and Alexkor Limited and the Government of South Africa, Case No. 488/2001, para. 8 (Mar. 24, 2003).
} 
survived and extended to the current legal regime. The judges ruled that the Richtersveld community's customary right of ownership had survived the annexation by the British Crown as "these rights constituted a 'customary law interest' and consequently a "right in land'."42 As noted by the Court: "[A]n interest in land held under a system of indigenous law is thus expressly recognised as a 'right in land,' whether or not it was recognised by civil law as a legal right." 43 The Court ultimately recognised the Richersveld right to land based on their "customary law interest under their indigenous customary law entitling them to exclusive occupation and use of the subject land and that its interest was akin to the right of ownership held under common law." 44

Both the company and the government challenged the ruling in front of the Constitutional Court alleging that the court of appeal was wrong in holding that the community had customary law interest in the subject land. A central aspect of their challenge was based on the colonial history of the land claim. Alexkor's representatives put forward the fact that after annexation in 1847 by the British the land was not been granted under any form of tenure, as a result the British Crown became the only legal owner. Hence, from their perspective the community had lost its rights to land in 1847 as a result of the annexation. Joining the Supreme Court of Appeal, the Constitutional Court rejected this argument highlighting that colonial rules had not extinguished the customary land rights of the community. In highlighting the legal value of customary indigenous peoples' land rights, the Constitutional Court stated: "indigenous law feeds into, nourishes, fuses with and becomes part of the amalgam of South African law."45

This ruling constitutes an important decision not only for the concerned community but also for many other indigenous communities who have also faced serious discrimination and non-recognition of their rights to land in South Africa. Due to the very unique post-apartheid legal regime on which this decision was based it is hard to foresee how such decision might translate to other jurisdictions outside South Africa. Nonetheless some aspects of this decision could offer some relevant legal developments outside the borders of South Africa, notably based on the fact that it highlights that colonisation and its following post-colonial legacy has not extinguished indigenous peoples' land rights. This case also highlight the importance of the formal recognition of indigenous customary land laws. The cohabitation between customary laws and formal laws is extremely relevant for the whole continent as most indigenous peoples still predominately refer to customary land tenure systems as their main legal norms when it comes to land rights.

\footnotetext{
42 Id. at para. 8.

43 Id. at para. 9.

${ }^{44}$ Id. at para. 27.

${ }^{45}$ Alexkor Limited and the Government of South Africa v. The Ritchersveld Community and Others, Case CCT 19/03, at 51 (Oct. 14, 2003).
} 


\section{B. Land and Natural Resources in Botswana}

Nearly at the same time another important legal battle on land rights was taking place across the border in Botswana. In the case concerning the CKGR mentioned earlier, one of the central issues for the court was to determine whether the indigenous community had any right to the land, and if so if their forced removal was illegal. To address this issue the judges had to examine the issue of survival of customary land laws and the nature and value of possession as constituting title. The High Court ruled in favour of the indigenous community highlighting that their possession based on customary law subsisted the creation of the game reserve both under colonial rules and in the post-independence period. The court highlighted that the forced removals of the concerned community and the denial of their rights to occupy their ancestral territory were unlawful and unconstitutional. As noted by ones of the judges, the establishment of the game reserve did not extinguish their customary land rights so the applicants "were in possession of the land that they lawfully occupied." 46 The court unanimously recognised the right of the applicants to live and reside in the reserve. In a similar approach to the one adopted by the judges in South Africa, an important element of the ruling was the recognition of the nonextinguishment of indigenous peoples' customary land rights under colonial rules and post-independent legislation.

However, there were some serious limitations within the ruling of the High Court in 2006. First, the court ruled that the stopping of services was lawful and the government was not required to restore basic and essential services in the reserve. This led to the impossible situation for the community of having been recognised their rights to live on their ancestral land but not having the right to the water that could allow them to live on the land. During the forced relocation of the community outside the reserve, the authorities had destroyed several water tanks and sealed off some of the essential boreholes. This led to another court case which started in 2010. This time the focus was on the recognition of their right to access and use water resources. In particular the applicants sought permission to re-commission, at their own expense, a borehole that had been closed by the government. The applicants lost their case in first instance, the judge stating that "The Basarwa have chosen to settle in areas far from those facilities. They have become victims of their own decision to settle an inconveniently long distance from the services and facilities provided by the government." This was overturned in appeal when the community was recognised its fundamental rights to access water. The court ruled that since the applicants were found in "lawful occupation" of their ancestral lands, they should have the right to drill their boreholes for domestic purposes. It has been a long legal battle for the

\footnotetext{
${ }^{46}$ Statement from Judge Phumpahi, Central Kalahari Legal Case No. MISCA 52/2002 in the Matter between Roy Sesana, First Applicant, Keiwa Setlhobogwa and 241 others, Second and Further Applicants, and the Attorney General High Court of Botswana (2006)
} 
residents San community of the game reserve to gain their right to live on their lands, taking four different cases of litigation. ${ }^{47}$

Some important lessons can be drawn from such process, and notably the importance of recognising the fundamental connection between land and natural resources. Indeed for many indigenous community, and not only the San, land rights relate to the rights to use and access the natural resources found on their territories, including water rights and also hunting and gathering rights. The second limitation of the case relates to the fact that the 'legal' victory concerns only a limited number of the original inhabitants of the reserve as only the applicants listed got the right to go back, not the whole communities who were forcedly removed. Whilst the case has often been perceived to be a victory for the San of Botswana, the reality is different as the case was filed to the court with the name of 243 specific applicants. Hence the decision concerns only these applicants not the entire concerned San communities. This restriction came as a late realisation for many other residents of the reserve. This has also served as a lesson across the border as a case which was launch by several San communities in Namibia has been using the framework of class action rather than individually based claim.

Overall, looking at both cases of litigation in South Africa and Botswana, what is emerging is the importance of a legal theory on 'indigenous customary title'. In both situations, the concerned communities won their case based on the recognition that the radical colonial title to land ownership, and its ensuing post colonial legacy, have not 'extinguished' indigenous peoples' land rights, and that their rights to land form part of the contemporary legal framework governing land laws at the same level than other statutory and jurisprudential rights. Comparative legal analysis has played an important role in these decisions. The courts have highlighted the importance of integrating indigenous peoples' customary land rights within the mixed and plurilegal African systems. It is in this mix of common law, Roman-Dutch, civil statutory laws and customary law that a specific African approach to the meaning and content indigenous peoples' land rights appears. In terms of legal theories regarding indigenous peoples' land rights, it is important that the recognition of possession and customary law as a source of land rights does not come with the limitation of extinguishment which has been developed in common law countries such as Australia and Canada. Indeed under the common law doctrine, Aboriginal or Native titles are submitted to the "illegitimate assumption of State power to extinguish such title."48 Instead the courts in South Africa and Botswana adopted a less State centric approach to indigenous peoples' land rights putting forward the power of customary laws. Whilst, to some extent the approach builds on the Aboriginal/Native title theories, it includes indigenous land laws within a much more equalitarian footing with other

\footnotetext{
${ }^{47}$ More recently in 2014, five residents have lodged a new claim for the recognition of their right to hunt within the reserve, as without the possibility to hunt life in the reserve is impossible.

${ }^{48}$ Final working paper prepared by the Special Rapporteur, Mrs. Erica-Irene A. Daes, Indigenous peoples and their relationship to land, UN Doc. E/CN.4/Sub.2/2001/21 (2001), at 38
} 
competing right. This approach is very specific to Africa, and arguably more compelling, as indigenous title seems to be less fragile and less totalising as it is not submitted to a nearly impossible burden of proof that marks the common law theories on aboriginal title. ${ }^{49}$ The emergence of an African indigenous title theory, or as captured by McHugh the 'creolisation' of indigenous title theory, is based on a more atomised place for customary collective rights. ${ }^{50}$ It is also developed with a better inclusion of human rights principles of equality and non-discrimination which were clearly articulated by the petitioners and their legal teams as essential element of land rights.

\section{LITIGATING AGAINST CONSERVATION, DEVELOPMENT AND TOURISM}

For many indigenous communities across the continent, wildlife conservation, economic development and tourism have often become synonymous with destitution and loss of lands. ${ }^{51}$ In the name of development or conservation, indigenous peoples have often been pushed away from their traditional lands, losing access to their ancestral territories and the essential natural resources contained on these lands. ${ }^{52}$ Several indigenous communities have suffered from "aggressive conservationist initiatives" that have often resulted in their forced expulsion from natural reserves or other wildlife protection areas. ${ }^{53}$ The other major negative factor affecting indigenous peoples relates to large-scale developmental projects on indigenous territories, including for examples dams, logging, mining and other related infrastructures. These developments regularly lead to forced eviction, loss of lands and livelihoods, destitution and environmental degradation. All these initiatives are usually undertaken in the name of development. When it comes to development and exploitation of natural resources, States often put forward the argument that they cannot stop these large-scale developments that will bring significant wealth to the whole country to protect just a few marginalised indigenous peoples. ${ }^{54}$ Tourism is another 'plague' affecting indigenous peoples across the continent. The massive boost of the tourism industry over the last few decades has had a dramatic impact on indigenous peoples as their territories are often located on tourism hotspots. In this context, tourism often

\footnotetext{
${ }^{49}$ See P. McHugh, Aboriginal Title: The Modern Jurisprudence of Tribal Land Rights (OUP, 2011)

${ }^{50} \mathrm{P}$. McHugh, personal communication during the Half-Day Workshop on 'Adjudication and Indigenous Peoples', Queen Mary University, 27 January 2016

${ }^{51}$ See Laura A. Young and Korir Sing'Oei, Land, livelihoods and identities: Inter-community conflicts in East Africa (MRG, 2011)

52 See Human Rights Committee: Ivan Kitok v. Sweden, Communication No. 197/1985, Report of the Human Rights Committee, GAOR, 43th Sess., Supp. 40 (A/43/40); Lubicon Lake Band v. Canada, Communication No. 167/1984 (26 March 1990), UN Doc. Supp. No.40 (A/45/40) at 1 (1990); Hopu and Bessert v. France, Communication No.549/1993, UN Doc. CPR/C/60/D/549/1993/Rev.1 (29 December 1997)

53 See: M. Sapignoli and R. Hitchcock, People, Parks, and Power: The Ethics of Conservation-Related Resettlement (forthcoming 2016)

${ }^{54}$ See: M. Blaser, Harvey A. Feit, and G. McRae (eds.), In the Way of Development: Indigenous Peoples, Life Projects and Globalization (Zed/IDRC 2004).
} 
results in forced relocation, loss of livelihoods and the exploitation of indigenous peoples' own cultural asserts without due recognition and benefits. Hence it is not surprising that most cases of litigation concern these three 'plagues': development, conservation and tourism. For example, on the aforementioned case from Botswana, one of the central arguments in defence of the forced removal of the community by the government was that such removal was done in the interest of conservation, tourism, and development. ${ }^{55}$ Likewise the case in South Africa concerned mining interests and development. All these issues of development, conservation and tourism were also at the heart of the litigation between the Endorois community and the government of Kenya.

\section{A. The Right to Development and the Endorois in Kenya}

The Endorois are a predominantly pastoralist society living in Kenya's Rift Valley, and their practice of pastoralism has consisted of grazing their animals in the lowlands around Lake Bogoria. A Game Reserve has been established on their territory, and several game lodges, roads and a hotel have been built on their land. The government has also granted a concession for ruby mining on part of the territory. After years of frustrating negotiations and litigation at the national level, the Endorois community decided to take their case to the African Commission on Human and Peoples' Rights. ${ }^{56}$ The Endorois alleged violations resulting from their forced displacement of from their ancestral lands, the failure to adequately compensate them for the loss of their property, the disruption of their pastoralist way of life and violations of the right to practise their religion and culture, as well as the overall process of development of the Endorois people.

A central argument of the government was that tourism and the exploitation of natural resources (notably ruby mining) would bring significant resources to the region. The government highlighted the fact that the project for tourism around Lake Borogia was seen as a potential positive development and all the revenues raised by the Game Reserves were re-used to support development projects carried out by the County Council for the area. One of the arguments put forward by the government was that the establishment "of a Game Reserve under the Wildlife laws of Kenya is with the objective of ensuring that wildlife is managed and conserved to yield to the nation in general and to individual areas in particular optimum returns in terms of cultural, aesthetic and scientific gains as well as economic gains as are incidental to proper wildlife management and conservation." 57 Overall, the government was arguing that other communities, and the country as a whole was to benefit from the

\footnotetext{
${ }^{55}$ Also worth noting that even though mining was not put forward as a ground for relocation, there is now a diamond mine in the southeast of the reserve, a planned copper-silver mine in the northwest, and several mining prospects pending elsewhere.

${ }^{56}$ Communication 276/2003, Centre for Minority Rights Development (Kenya) and Minority Rights Group International on behalf of Endorois Welfare Council v Kenya (2010)

57 Id., para. 178
} 
development. They also added that the community knew about the mining concession and would benefit from its exploitation. The government concluded that "the task of communities within a participatory democracy is to contribute to the well-being of society at large and not only to care selfishly for one's own community at the risk of others." 58

On their side, the Endorois argued that these developments were taking place in violation of their right to development protected under Article 22 of the African Charter which states: "All peoples shall have the right to their economic, social and cultural development with due regard to their freedom and identity and in the equal enjoyment of the common heritage of mankind." Based on this article the Endorois highlighted that the imposed decision of the government to proceed with these developments on their lands put them into a situation of disenfranchisement by losing access to a land essential to ensure the maintenance of their pastoralist way of life. The pastoralist community contended that the government had violated their right to development by its failure to adequately involve them in the development process taking place on their customary lands as well as its failure to ensure the continued improvement of the community's well-being. They highlighted that in forcing such developmental projects on their lands the government "did not embrace a rights-based approach to economic growth, which insists on development in a manner consistent with, and instrumental to, the realisation of human rights and the right to development through adequate and prior consultation." 59 It is not so much the legitimacy of the decision of the government in turning the land into a tourism and wildlife reserve that the community was contesting but rather the way the decisions were made and notably the lack of consideration to their culture and survival. They emphasised that the Game Reserve and their pastoralist way of life should not be mutually exclusive. Linking self-determination and development, they stressed that they had "suffered a loss of well-being through the limitations on their choice and capacities, including effective and meaningful participation in projects that will affect them." 60 The community highlighted that "self-determination also include the ability to dispose of natural resources as a community wishes, thereby requiring a measure of control over the land." 61

In terms of legal jurisprudence, the position of the two parties on the meaning of the right to development made it a very compelling case since there have been very few cases of litigation on the right to development. Under international human rights law there has been debates on the theoretical implications of the right to development but very rare instances of legal adjudication. ${ }^{62}$ In general the right to development has

\footnotetext{
58 Id., para. 270

59 Id, para. 135

60 Id., para. 129

61 Id., para. 129

${ }^{62}$ For a review and references, see: M. Salomon and A. Sengupta, "The right to development: obligations of states and the rights of minorities and indigenous peoples" (Minority Rights Group
} 
not been seen as a justiciable right. Regarding the scope of the right to development, the African Commission highlighted that "the right to development is a two-pronged test, that it is both constitutive and instrumental, or useful as both a means and an end." 63 Adopting a pragmatic focus, the Commission concentrated on two principal issues: (1) to what extent was the community was (or not) consulted prior to the establishment of the wildlife reserve on their territories and (2) whether such development provides benefit to the concerned community. The Commission found that the lack of "meaningful participation" by the Endorois who "were informed of the impending project [on their land] as a fait accompli" was a violation of the right to development. The Commission found that the government had violated the right of the indigenous community to their culture, land, and development. It rejected the argument put forward by the government that the community's rights should be 'sacrificed' in the name of development, tourism and conservation. Instead the Commission underscored that a fair balance should be struck insuring that the community would also benefit and participate to these developments. From a global legal perspective, this aspect of the case is extremely appealing since there are few cases that have specifically focused on the right to development in the context of large-scale developmental projects taking place on indigenous peoples' territories. This legal reasoning could have some important echoes across the continent as most government usually justify the forced displacement of marginalised indigenous communities on the basis that it is necessary to allow development, conservation and tourism.

\section{B. Tourism, Corporations and The Maasai in Tanzania}

Three indigenous Maasai communities in northern Tanzania find themselves in the middle of a complex legal battle to reclaim their rights over their ancestral lands and resources following the wrongful acquisition of their lands by private corporations. ${ }^{64}$ In 2010, the concerned Maasai villagers had filed a petition to the local High Court in Arusha after they were forced from their land and blocked from vital water sources to make way for a luxury safari camp near the world-famous Serengeti National Park. The safari camp is run by a subsidiary Tanzania entity of a US-based Safari Company, Thomson-Wineland Adventures Inc., also known as Thomson Safaris. In 2006, Thomson's affiliate, Tanzania Conservation Ltd. (TCL), acquired 12,617 acres of land known as "Sukenya Farm," which had traditionally

International, 2003); D. Aguirre, The Human Right To Development In A Globalized World (2008); K. De Feyter, World Development Law (2001); M. Salomon, Global Responsibility For Human Rights: World Poverty And The Development Of International Law (2007).

${ }^{63}$ Endorois Case, supra note 55, para. 277

64 Mondorosi, Sukenya and Soitsambu Village Councils v Tanzania Breweries Limited, Tanzania Conservation Ltd, Ngorongoro District Council, Commissioner for Lands and Attorney-General (Tanzania), see: http://minorityrights.org/law-and-legal-cases/mondorosi-sukenya-andsoitsambu-village-councils-v-tanzania-breweries-limited-tanzania-conservation-ltd-ngorongorodistrict-council-commissioner-for-lands-and-attorney-general-tanzania/ 
been used by the Maasai communities. Their legal claim reposes on a complex and historical battle over the land which started in 1984 when the government-owned Tanzania Breweries Limited (TBL) acquired 10,000 acres at Sukenya Farm, without any consultations, consent or compensation of the local communities. The aim of the brewery company was to cultivate barley and wheat, but ultimately it only used a very small parcel of the land (700 acres), while the remaining part of the land was in usage by the Maasai communities for grazing and watering their livestock. In 2006, the land was then sold to the Tanzania subsidiary of Thomson Safari without any form of consultation, or involvement of the indigenous pastoralists communities.

The indigenous communities challenged the legality of the acquisition of their lands in a petition to the High Court. Their claim was notably based on the fact that it did not follow required conditions of consultation and compensation. In their complaint to the court the villagers also highlighted that their continuous peaceful occupation of the land since it was wrongly acquired in 1984 made them the rightful owner of the land under the theory of acquired rights. The asked the court to recognise the illegality of the acquisition of the land by the US based Safari Company. In their application the villagers requested the court to revoke the company's land title, prevent them from converting the land's designated use from pastoralism to tourism, and award damages for the injuries they have suffered due to their exclusion from the land. However, in 2015, the High Court ruled against the villagers apart from a minor point concerning an illegal transfer of part of the land, but no damages were awarded to the communities. ${ }^{65}$ Whilst this undoubtedly represents an important setback for the applicants, there are some important legal aspects of their legal battle that need to be highlighted.

An important aspect of the case relates to the allegation against the act of the corporation based in the US. Legally the communities could not take direct legal action against the US based corporation in a local court as it had operated under its subsidiary based in Tanzania. With the assistance of Earth Rights International, an international NGO based in the US, the three Maasai communities turned to a US federal court to support their on-going legal battle over the land they lost to Thomson Safaris. ${ }^{66}$ The federal court action was filed under the Foreign Legal Assistance (FLA) Statute (28 U.S.C. $§ 1782$ ), a law that allows people to obtain documents and information from individuals or companies in the US to support foreign legal proceedings. The aim of the legal action in the US was to show that Thomson Safari knew that the land confiscation was illegal and were aware of the extremely negative consequences that such illegal acquisition would have for the communities. The documents and information that were made available through this legal proceeding in

\footnotetext{
${ }^{65}$ See: "MRG deeply disappointed by Arusha Court land rights judgment against Loliondo Maasai", at: http://minorityrights.org/2015/10/28/mrg-deeply-disappointed-by-arusha-courtland-rights-judgment-against-loliondo-maasai/

${ }^{66}$ See: http://www.earthrights.org/media/maasai-villagers-turn-us-courts-information-abusiveevictions-us-safari-company
} 
the US could be essential to support the claim of the communities in Tanzania. It was also an innovative and novel way - not much used in the US - of bringing the litigation 'home'.

Whilst the situation in this case might sound very specific it reflects on the situation faced by many indigenous communities across the globe. In many situations private corporations acquire indigenous territories under quite similar processes using nationally or locally registered sub-contractor or subsidiaries to conduct their operations on indigenous territories. From this perspective, the complexity of the legal action that the Maasai villagers had to go though is a good indicator of the complexity of the legal strategy that many indigenous communities have to face when multinational corporate interests are invading their territories. It also shows how international supports from international actors could be crucial to engaged in such transnational litigation.

\section{LACK OF IMPLEMENTATION, STRATEGIC LITIGATION AND LEGAL EMPOWERMENT}

For many marginalised indigenous communities taking legal action is a daunting process. It is complex, technical, lengthy and costly. Moreover, there is no guarantee of wining a case, and even in case of victory the prospects of implementation are often tenuous. Nonetheless, as this article has examined many very marginalised indigenous communities are engaging with litigation. This last section wishes to examine some of the hurdles faced by indigenous peoples in engaging with litigation with the aim of offering a reflection on the reasons that are pushing indigenous peoples to engage with litigation. The aim is to examine to what extent litigation is part of a strategy for social change (referred to as strategic litigation) and to what extent it participates to the legal empowerment of marginalised indigenous communities. To undertake such analysis, the following discussion is based on three important phases of the litigation process, namely: (1) the pre-trial development of a legal strategy and the process of evidence gathering by the communities and their legal support team; (2) the trial phase in itself, which is often a lengthy and costly process; (3) and the post-ruling phase, which even in the event of a victory in court does not signal the end of the legal battle for implementation.

\section{A. Pre-Trial Strategy: Community and Evidence Gatherings in Uganda}

The decision to take legal action by the Batwa represents a compelling experience about community mobilisation and the development of a legal strategy before going to litigation. The Batwa do not live as one united community but live in scattered small communities, squatting either at the borders of the lands they have been evicted from or in the vicinity of villages or towns that are near the parks. In 2000, several community leaders, with the support and involvement of outsiders and 
NGOs, decided to establish the United Organisation for Batwa Development in Uganda (UOBDU) as an umbrella organisation to support the Batwa to unite and engage in informed advocacy for their rights. UOBDU quickly became a place for communities to voice their concerns and share similar stories of discrimination. The organisation quickly became the main avenue for them to express their concerns to the government, notably through numerous exchanges and discussions with local councils, various government departments as well as the Parliament of Uganda. Under the umbrella of the organisation the Batwa also started to address international and regional human rights mechanisms, which led to the issuance of clear guidance on how Uganda should address the human rights situation of the Batwa. However, over the years of negotiations and push by international and regional human rights institutions, the hope of achieving remedies outside the courts faded as no concrete measures were put in place by the national authorities. Worst the overall situation of the Batwa kept leading them towards more impoverishment and discrimination. Based on the lack of proper engagement from the local and national authorities, the Batwa, via their traditional leaders and through discussions with most members of the communities, decided to take the government to court.

Initially most of the Batwa would have preferred the option of dialogue and negotiations. The predominant view from most of the members of the community was in favour of not 'attacking' the government in court, as authorities were still seen as important and respectful allies necessary to support them. However, after a few years of frustration and lack of any proper engagement by the authorities a debate started within the community about the next step to follow. In that process, the Batwa had put in place a very efficient forum for discussion when representatives of many communities will gather together to discuss the process ahead. Over the years that forum has proven to be a very powerful agent for the Batwa to express their issues, but also to get a sense of empowerment by sharing their common experiences and learn about their rights. Through this forum the Batwa started to use a common language to express their grievances. Hence when the issue of taking an eventual legal action arose, the Batwa had already been developing a common platform to engage with the issues to be put forward. This forum was used to express grievances and translate these into a legal language. It is within that forum that slowly the decision to push for litigation emerged. The representatives of the communities would report back to their communities and then report back to the forum about the decisions from the other members. As such the decision to take legal action was taken collectively though a long process of dialogue.

Once the decision was put forward to take legal action, the forum was then used as a platform to build the legal argumentation. An important aspect was to gather evidence to bring to court. Generally bringing evidence on land and resources ownership is a serious challenge for indigenous communities. As they usually do not have an official administrative proof of ownership they have to rely on oral testimony and community members' evidence of usage and possession of the land. Increasingly 
communities are using mapping technologies, such as GPS and GIS, to support their claims. The Batwa faced all these difficulties, adding to the fact that their removal has taken place over a long period from the 1920's until the 1990's. It meant that many of the members of the community had never 'legally' live on their ancestral territories. Hence the decision was made to record evidence from the eldest of the community who had lived on the concerned lands and had faced the eviction. In 2011 the Batwa created three-dimensional models of both Bwindi and Mgahinga national parks which depicts their spiritual and cultural attachments to the forest and specific sites within the forest. At the time of writing, the case has yet to be heard and ruled by the Constitutional Court, however many of the issues that came before launching the case to the court highlights some important elements regarding the process of legal empowerment which goes with a community deciding to use litigation and the process of evidence gathering.

\section{B. Strategy to Support Litigation in Botswana}

The aforementioned case from the High Court of Botswana is longest and most expensive case ever run in the country' legal history. The first court case itself run from 2004 to 2006, but the legal proceedings started in 2002, and ultimately two other cases followed in 2011 and 2015. The fact that in 2006 it was estimated $10 \%$ of the original applicants in the legal case had died since the CKGR High Court case began gives a tragic indication on how strenuous such long term legal action can be on a marginalised and deprived community. ${ }^{67}$ Apart from this dramatic aspect, litigation is also a costly process, especially since these cases are usually extremely lengthy and technical. Indigenous communities are usually disenfranchised and do not have the necessary monetary means to support such long process of litigation. From this perspective, all the cases mentioned so far have received some support from legal firms and civil society organisation to support them. In the case of the San in Botswana, Saugestad has analysed how the support from external actors was essential in supporting the indigenous communities both in terms of legal analysis, via the involvement of international lawyers, funding, via the support from international NGOs, and also advocacy via the use of international media and lobbying groups. ${ }^{68}$ As she noted: "there is no way a group of poor illiterate San could have raised the case on their own (..)." Originally the applicants and their legal team had envisaged that the court case would take about one year, instead of the nearly 11 years it took. This meant that financial resources to sustain the case were clearly not sufficient. After the first phase of the case, the claimants decided that it would be a good idea to hire more lawyers to their defence team. For that purpose a fund-raising tour of the

\footnotetext{
${ }^{67}$ M. Sapignoli and R. Hitchcock, "A Chronology of the Central Kalahari Game Reserve: Update III, 2002 - 2012", Botswana Notes and Records 45 (2013), pp. 52-65.

${ }^{68} \mathrm{~S}$. Saugestad, "Impact of international mechanisms on indigenous rights in Botswana", 15 (1) International journal of human rights (2011), 37-61
} 
US which was sponsored by the Indigenous Land Rights Fund and the Kalahari Peoples Fund was initiated. ${ }^{69}$

The situation of the San in the CKGR in Botswana has received a significant coverage and involvement from INGOs, including some of the most established international organisations working in support of indigenous peoples. The International Work Group for Indigenous Affairs (IWGIA) has funded First People of the Kalahari (FPK) which was instrumental in supporting the capacity-building of the community with the legal case. ${ }^{70}$ Cultural Survival, one of the largest NGO supporting indigenous rights globally has been extremely proactive in producing numerous articles, reports and press releases on the central Kalahari. Survival International has been especially active producing 'Urgent Action Bulletins' on the central Kalahari situation, and by providing some funding and support to the legal team involved on the side of the applicants in the court case. As highlighted by Sapignoli an important element which made the San received such a strong support from western NGOs was notably based on the San "receptacle of Western imaginaries of anti-modernity and otherness, as peoples" who has such became "a focal point of conflict over different understandings of human worth, dignity, and equality." 71 This involvement from international NGOs led the government to claim that the case was led by foreigners. International and regional human rights organisations also played a significant role in the background of the case, by notably putting pressure on the authorities regarding the situation in the CKGR. ${ }^{72}$ For example, in 2005 in the midst of the legal case two members of the Working Group on Indigenous Populations/Communities of the African Commission on Human and Peoples' Rights visited Botswana. ${ }^{73}$ Then, in 2006 the African Commission on Human and Peoples' Rights expressed concerns to the government about the treatment of the people of the Central Kalahari. The (former) UN Special Rapporteur on the human rights and fundamental freedoms of indigenous peoples has also played a proactive role in reporting on the situation and visiting the country.

The involvement of international actors was not always a positive force as it created some dissensions amongst the various local and national organisations previously involved. For example, some of the local NGOs pulled out of the negotiations because they felt that the approaches being employed by Survival

\footnotetext{
${ }^{69}$ The lack of funding means that now the organisation First People of the Kalahari which was set up to support the court action has run out of money and closed down.

${ }^{70}$ See: R. Hitchcock and M. Enghoff, Capacity Building of First People of the Kalahari: An Evaluation (International Work Group for Indigenous Affairs, 2004).

${ }^{71}$ M. Sapignoli, "Dispossession in the Age of Humanity: Human Rights, Citizenship, and Indigeneity in the Central Kalahari”, (2015) 25 (3) Anthropological Forum, pp. 285-305

72 See M. Sapignoli, Local Power through Globalized Indigenous Identities: The San, the State, and the International Community', (Unpublished PhD Dissertation, Essex University -2012).

73 See ACHPR 2008
} 
International were too aggressive and counter-productive. ${ }^{74}$ As analysed in great details by Saugestad the involvement of so many international actors, and the polarisation that it created between the different local actors "has paradoxically endangered the possibility of generating a stronger locally-based movement advocating for San rights." 75 The international involvement was also an essential ingredient in the establishment of the legal team. The legal team was composed of lawyers from South Africa who were joined by a British lawyer when Survival International got involved in the case. The role of the lawyers raises several issues, not only in this case but also more generally when it comes to litigation on indigenous rights. The legal procedures being usually extremely complex and jargonised, lawyers representing the indigenous communities tend to become the leaders of the legal strategy rather than the community. In the case of Botswana, Saugestad noted that "once the case proper started, the formalities of the legal process took control, the lawyers took centre stage, and the applicants became spectators." 76

This case shows how essential it was for the applicants to get international support, but it also highlight the potential pitfalls of this involvement. The international involvement played a positive role in supporting the legal argumentation and the advocacy around the case. It was also an essential element in the case management and in ensuring the financial sustainability of the court action. However, it has also created serious tensions within the national and local setting creating dissension between the national human rights actors and the communities. Ironically it participated to the lack of direct empowerment of the most concerned individuals who became secondary actors to their own court case as the centre stage was taken over by international actors, including INGOs and lawyers. In this context it is essential to ensure that a cohesive strategy between all partners in the court case is define and respected to ensure the direct participation and consultation at all levels of the concerned communities, this is certainly an important lesson to be learnt from in other cases of litigation which involve the heavy involvement of external actors.

\section{Strategy to Support Implementation of the Endorois Decision}

Wining a case is undoubtedly an extremely positive outcome, however it is not the end of the road as very often the process of implementation is in itself an arduous road to follow for communities engaging with litigation. As noted earlier, in 2010 after years of litigation, the Endorois of Kenya won an important legal battle when the African Commission established that the government should restitute their ancestral lands, ensure unrestricted access to Lake Bogoria, pay adequate compensation for all

\footnotetext{
${ }^{74}$ See J. Solway, "Human Rights and NGO 'Wrongs': Conflict Diamonds, Culture Wars, and the 'Bushman question'." (2009) 79 (3) Africa 329-343.; S. Saugestad, "Impact of International Mechanisms on Indigenous Rights in Botswana." (2011) 15 (1) The International Journal of Human Rights 37-61.

75 Ibid, Saugestad, 2011, at 56

76 Ibid, Saugestad, 2011, at 44
} 
losses suffered, pay royalties regarding existing economic activities, and engage in dialogue with the complainants regarding future development on their territory. That decision came in 2010, however six years later, at the time of writing, the decision still remains to be implemented by the Kenyan government. Unfortunately this is not an isolated story as across the globe many indigenous communities who have won a case are still awaiting for implementation.

From this perspective an interesting development is taking place in Kenya where the community has been leading a process to support the implementation of the decision. The community established the Endorois Welfare Council as a platform to support their capacity in supporting the litigation. The council now plays a considerable role to catalyse the effort and the push to support the community to effectively negotiate with the government regarding the implementation of the decision. Working alongside other national and international organisations, Minority Rights Group (MRG) has been extremely proactive holding strategic meetings, organising workshops with leaders of the Endorois community on different options of land restitution and compensation, conducting surveys on immaterial losses, analysing data on material losses, building the capacity of the Endorois Welfare Council to seek implementation, organising paralegal trainings, supporting community outreach and seeking the active involvement of African Union and United Nations bodies, including the ACHPR holding one of only two hearings on implementation and issuing its first ever resolution on non-implementation. As a result of such proactive civil society push, in 2014 the government established a 'Task Force' to address the ACHPR's decision. Whilst there are some serious limitations regarding this task force, notably the fact it is mainly composed of government officials, and that its mandate is to "study the Decision", it nonetheless represents an important platform which has emerged following the persistent push from the civil society to support the implementation of the legal decision. Moreover, due to the civil society push there has been some movements on the part of the government which at the start was quite lethargic regarding the implementation of the decision. This experience on supporting the implementation could be shared across the continent as non-implementation is not unique, nor is it specific to having been adopted by a regional institution rather than national courts. For example, so far the government of Botswana has failed to implement the ruling issued by the High Court in 2006. In many ways the lack of implementation raises the question of the viability and usefulness of litigation. As highlighted litigation takes lots of resources, time and energy from the communities, hence the prospect of non-implementation puts serious doubt the viability of using courts as an agent of change.

Nonetheless what the litigation process in Kenya as well as the other cases that have been examined in this article are showing is the important role that litigation plays as a tool to support legal empowerment of the concerned communities. In all the situations examined the concerned communities are extremely marginalised, and are usually facing some serious forms of discrimination from the rest of the society. They 
have highlighted that taking legal action is often an important catalyse to support their affirmation as equal citizens of the State entitled to a voice. As powerfully captured by Sapignoli in the context of Botswana, litigation can have important effects as not only it put into the open the illegality of the government's action against its own citizens, but it also "reinstated the applicants' 'right to have rights', as those who, as citizens, can bring their own government to court and refer to state laws to have their rights recognised." 77 This analysis could be replicated in the context of Kenya, but also more generally for all the indigenous communities who have been engaging with litigation. It transpires that outside the pure issue of victory or not in court, litigation supports community building and push communities to develop a legal strategy to get the recognition of their rights. In itself this process contributes to the empowerment of the communities in reclaiming their rights and becoming suddenly visible and entitled citizens of the State. From this perspective engaging in litigation can be seen as an important element in terms of a larger strategy for visibility and political empowerment despite the potential lack of implementation of the decisions.

\section{CONCLUSION}

As indicated in the introduction this article has two main objectives, first to examine to what extent a jurisprudence on indigenous peoples' rights is emerging across the continent, and secondly to explore the challenges and limitation of using litigation as a tool for social changes. In terms of the development of an African jurisprudence on indigenous peoples' rights, the current wave of litigation on indigenous peoples' rights supports the emergence of a systematic set of principles. This includes the increased reference to the legal term 'indigenous peoples' as developed under international law, notably as a way to recognise the historical marginalisation and discrimination faced by indigenous communities. Courts have started to refer to the rights of indigenous peoples as a way to condemn governments for not taking proactive and systematic legal measures to recognise indigenous peoples' rights. In this context it could be argued that the legal category of 'indigenous peoples' has allowed communities (sometimes divided by colonisation) to re-assert their rights, using the concept of 'indigeneity' as a means of defining themselves as peoples entitled to specific rights. The references to indigenous peoples' rights as defined under international and regional law has allowed communities to highlight that: (1) they are different from the majority population; (2) that they have been historically been mistreated and discriminated against; and (3) that this treatment occurred in part because of their lifestyles and distinct cultural attributes.

\footnotetext{
77 M. Sapignoli, "Dispossession in the Age of Humanity: Human Rights, Citizenship, and Indigeneity in the Central Kalahari", (2015) 25 (3) Anthropological Forum, p. 18 (references omitted)
} 
The related factor emerging from the cases examined relates to the emergence of an African jurisprudence on land rights and natural resources for indigenous peoples. As mentioned earlier there is the emergence of an African approach to land rights which tackles the inherent colonial land legacy by putting forward the fact that indigenous peoples customary land rights have not only survived colonisation and its ensuing independence, but also form part of contemporary land rights. In a general context when most of Africa is witnessing an intense 'land grab', the recognition of a specific right for indigenous peoples to land is certainly an important breakthrough. The other important factor of the emerging jurisprudence on indigenous peoples' rights relates to the narrative of development. Across the continent indigenous peoples are often the victims of imposed forms of development resulting in displacement, forced relocation and destitution. All the cases examined in this article highlight how courts are appearing as a possible way to challenge the top down narrative of development imposed by States by putting forward the need to recognise the rights of indigenous peoples in this context. In examining the condition that led to the acquisition of indigenous territories and the way development was used as a justification for their removal, courts are starting to engage with the issue. However, it is not yet entirely clear to what extent courts could become a place to challenge the dominant narrative on development which usually justified the removal of indigenous peoples from their lands on the grounds of nature conservation, development, and the need to support 'under-developed' segments of the society into modernisation. Whilst there are glimpses of the potential role that courts could play in this context, apart from the decision from the African Commission, there is yet no convincing engagement with the issue of development in the emerging jurisprudence. This is most probably the next important step into the development of a specific African jurisprudence on indigenous peoples' rights knowing how development, conservation and tourism are affecting communities across the continent.

The second set of remarks relates to the more practical aspects of engaging with litigation. As noted earlier litigation is a lengthy, technical and costly process usually requiring the involvement of external actors. This includes local/national/international NGOs with external funding. Based on the experiences of the communities who have engaged in this process, two important points seem to emerge. First, relying on this source of external support is unpredictable. NGOs are very often submitted to short term funding and objectives, whereas litigation is long term and unpredictable. In result it means that indigenous peoples have to rely on a multitude of changing actors to support their case. As examined in the case of Botswana, it is hard to develop a long-term strategy on litigation relying on several different sources of funding and support. The second related issue is that such involvement from external actors has implications regarding the way the legal strategy is developed. External actors will engage based on their own visions and interests in what should be put forward in the litigation. This might not always match and relate to the interest and vision of the concerned community. As noted earlier this could lead some serious tensions between the different civil society supporters but also within the communities. Importantly it 
also means that the communities could easily lose control on the content of the arguments put forward to the courts. The technicality of the legal language used by the lawyers, the judges and the NGOs can alienate indigenous peoples who are becoming secondary actors to their own court case. From this perspective the approach developed by the supporting organisations is an essential element of the court case, as it needs to be based on a very inclusive, open and clear participatory model. This takes time and energy, but it can result in an important empowering platform for the communities.

Finally, as a last remark, and to open the debate further, it is worth noting the irony that courts, which are a part of the legal and political systems that has discriminated against indigenous peoples, are being approached for remedies. Historically, law and legal institutions have played a significant role in the alienation and marginalisation of indigenous peoples. Indigenous peoples are asking the very system that has contributed to the prejudice to determine whether or not the prejudice is justified. This can surely never be the best path to solve the problem. As noted in all the cases examined, indigenous peoples have usually preferred to engage in negotiations with the government rather than litigation. Litigation came as a last resort after years of frustration. Litigation comes at the last possible remedy when dialogue has failed, offering an important last step in a strategy to get recognition of their rights. These cases provide a good illustration on how litigation can be used as a way to get political recognition (irrespective of the results or implementation of the cases), and how litigation can support the legal empowerment of extremely marginalised indigenous communities. The court process itself is only one part of the story, as engaging with courts demands a huge effort in term of political and structural organisations from the communities, an effort which contributes to their empowerment irrespective of the courts proceedings. 